\title{
Aspek-Aspek Hukum Internasional Dalam Rancangan Undang -Undang. Bencana Alam
}

\author{
Jawahir Thontowi
}

\begin{abstract}
Abstrak
The urgency of the presence of the Natural Disaster Act is due to the fact that a hight tecnology detection used to prevent natural disaster from happening is less effective than the use of legal instrument. In this contexts, however, Indonesian government should in the Draf of Natural Disaster Act acommodate the extemal components such as, internatinnal convention, status of IDP's as victims, and foreign assistance and international relief workwer. In Addition, The Draf need to explicitly contain certain legal nations like, effort of people's prevention, mitigation, rights and duties, and government responsibility. This includes legal advocacy and the people right to take legal action, when the government faits to fulfil the duties.
\end{abstract}

\section{Pendahuluan}

Pro-kontra pernyataan Presiden tentang gempa di Nias 28 Maret 2005, sebagai bencana lokal dan Aceh sebagai bencana nasional telah menyisakan pertanyaan bagi masyarakat. Benarkah penyataan tersebut sebagai perlakuan diskriminatif ataukah persoalan salah memahami pernyataan yang dikeluarkan dalam kondisi masyarakat. Nias sedang panik. Timbulnya persepsi negatif masyarakat terhadap pernyataan Presiden tersebut terkait dengan tiadanya parameter standar yang diatur oleh UU memang diakui. Namun, fakta bahwa sedikitnya perhatian masyarakat, baik domestik maupun asing terhadap bencana Nias tersebut dapat dipandang memperkuat sikap diskriminatif tersebut.
Terlepas pro-kontra, sejak bencana tsunami Aceh dan gempa di Nias, perhatian Pemerintah Indonesia sangat terbatas dalam melakukan pertolongan evakuasi, tanggap darurat yang cepat dan memuaskan masyarakat. Tanpa keterlibatan masyarakat internasional boleh jadi proses pemulihan belum terselesaikan. Tidak mengherankan, baik di Aceh maupun di Nias, pendistribusian jatah hidup masih terdengar di lapangan belum merata.

Perhatian masyarakat internasional yang dilengkapi dengan fasilitas pertolongan modem memang dirasakan manfaatnya. Sebagai bukti, pemerintah Singapore dan Auștralia segera mengirimkan kapal dan rumah sakit terapung ke Nias. Hal ini juga sama persis ketika Singapore, AS, Inggris, dan negaranegara lain ikut campur dalam melakukan 
evakuasi dan tanggap darurat di Aceh sekitar dua hari setelah peristiwa 26 Desember 2004 terjadi. Bantuan asing (foreign assistance) diminta atau tidak adalah jelas merupakan tuntutan nurani dari kewajiban masyarakat internasional (erga omness). Termasuk bantuan yang dilakukan oleh militer dari Amerika, Australia, Inggris, dan juga Malaysia dipandang tidak merupakan intervensi.

Namun, sekiranya terdapat peraturan hukum itupun tidaklah berarti bahwa penanggulangan bencana di Indonesia àkan berjalan tanpa hambatan. Di satu pihak, aturan-aturan internasional, praktik bantuan kemanusiaan melibatkan masyarakat interna-sional dan status IDP's yang disejajarkan dengan pengungsi merupakan problematika internasional tersendiri. Di pihak lain, kewenangan pemerintah untuk menetapkan kondisi bencana alam, tangguing jawab pemerin-tah, keberadaan organisasi nasional dan partisipasi masyarakat juga problem internal yang belum tentu mudah diselaraskan.

Karena itu, sebelum menjawab problematika têrsebut, perlu dijelaskan beberapa perimasalahain seperti berikut ini.

Pertama, apa dan bagaimana fenomena bencana alam. Kedua, bagaimana bencana dalaḿn perspektif Hukum Internasional. Ketiga, persoalan apakah yang secara substantif harus diformulasikan dalam UU/PPB. Keempat, institusi dan prosedur apakah yang perlu dibentuk sehingga hak dan tanggungjawab negara dan rakyat atau korban menjadi jelas. Terakhir, bagaimana pula partisipasi masyarakat', baik relawan domestik maupun asing dan perlindungan hukumnya ketika mereka melakukan kerja kemanusiaan.

\section{Fenomena Bencana Alam}

Dewasa ini para ahli geologi dan kegempaan menyimpulkan bahwa bencana alam bukan merupakan peristiwa tunggal yang bersifat alamiah semata. Melainkan terkait dengan perilaku umat manusia yang menyimpang dan rakus terhadap sumber kekayaan alam. Sehingga efek samping terhadap ketidakseimbangan ekosistem tersebut tidak dapat dicegah. Dalam al-Qur'an ditegaskan bahwa telah terjadi kerusakan di darat dan laut disebabkan akibat ulah manusia yang melebihi batas. Perbuatan yang menimbulkan kerusakan tersebut, baik bagi alam maupun tatanan masyarakat antara lain disebabkan oleh karena ulah tangan-tangan kekuasaan yang jahil dan tidak adil. 1

Secara ilmiah, validitasnya membuktikan melalui hubungan sebab akibat timbulnya bencana dalàm tiga kategori, bencana alam (natural disaster), bencana ulah manusia (man made disaster) dan bencana gabungan (complex disaster). ${ }^{2}$ Akhir-akhir ini diakui oleh pakar-pakar bahwa perilaku manusia berpengaruh terhadap timbulnya bencana alam. ${ }^{3}$ Teori tersebut sangat relevan, mengingat situasi Aceh tergolong pada bencana gabungan. Selain telah terjadi tsunami, juga sebelumnya telah timbul sengketa antara TNI dengan GAM dan menimbulkan bencana dan ancaman bagi masyarakat begitu kompleks.

'Qur'an Surat Ar-Rum: 41

- 2 Sarwidi, "Sebab Akibat Bencana Alam Terhadap Masyarakat Indonesia", Makalah disampaikan dalam Diskusi Terbatas IMPRESS, tanggal 26 Februari 2005.

${ }^{3} /$ bid. 
Ada pendapat yang mengatakan bahwa bencana alam timbul disebabkan olẹ banyak faktor. Misalnya kepedulian yang rendah terhadap ancaman bencana baginya, sehingga mudah melupakan pelajaran bencana yang diperoleh sebelumnya, persiapan dan antisipasi yang rendah terhadap ancaman bencana. Tidak menerapkan siklus manajemen bencana. Konsep pengetahuan mitigasi yang tidak diaplikasikan. Kekurangan tenaga ahli dan praktisi kebencanaan, standar yang belum jelas dalam sebuah kelompok masyarakat atau manusia. Ketamakan, kebodohan dan kemiskinan sehingga memicu terjadinya bencana. ${ }^{4}$ Konsekuensi logis dari bencana tersebut telah menimbulkan dampak dan resiko yang periu diantisipasi dengan adanya regulasi yang sistematis.

Dampak negatif dari bencana alam yang ditimbulkan bukan sekedar telah mengancam keamanan dan keselamatan manusia (human security), dan telah menjadi beban ekonomi negara dan masyarakat. Sebagai salah satu contoh, terlihat di penghujung akhir tahun 2004, bencana demi bencana terjadi secara berantai, mulai dari Alor dan Nabire. Terakhir Gempa dan tsunami yang meluluhlantakkan sebagian daerah di Nanggro Aceh Darussalam, korban tercatat kurang lebih 232.446, terdiri dari 117.552 meninggal,114.921 dinyatakan hilang. Tidak kurang dari 30.242 unit rumah dan bangunan lainnya hancur. Kemudian disusul dengan bencana banjir di Jawa Timur, tanah longsor Jawa Tengah, dan gempa vuikanik di Sumatra Barat.

Dampak negatif kedua, timbulnya pengungsi yang begitu besar jumlahnya. Catatan PBB tahun 2002, khususnya World Food Program (WFP) jumlah pengungsi domestik (IDP's) sekitar 1,392.091 jiwa dan bertambah menjadi sekitar 1.500 .000 jiwa. Boleh jadi angka pengungsi tersebut bertambah setiap tahun, mengingat korban tsunami, khususnya di Indonesia seperti di Nabire dan Aceh tidak kurang dari 500.000 jiwa. Jumlah tersebut terdiri dari 446,212 jiwa adalah pengungsi Aceh. ${ }^{5}$ Meningkatnya jumlah pengungsi telah berpengaruh besar torhadap stabilitas sosial, ekonomi, politik dan keamanan nasional. ${ }^{6}$

Dampak negatif ketiga, bencana terhadap sistem ekonomi nasional juga telah menjadi ancaman yang signifikan. Kerugian material untuk bencana Aceh diperkirakan $\$ 4$ s/d 4,05 milyar, equivalen dengan Rp 46 Trilyun Rupiah. ${ }^{7}$ Padahal pos yang tersedia dari APBN khusus untuk program tanggap darurat tersedia 2 Trilyun. Kesenjangan ini menciptakan peluang bagi Departemen terkait untuk mengalihkan biaya rutin menjadi biaya darurat. Itu berarti, anggaran untuk program rutin dapat terganggu.

Dampak negatif terakhir, yaitu tumpang tindih tugas, termasuk timbulnya kontradiksi kewenangan antara pemerintah dengan organisasi non pemerintah. Padatial dalam ketentuan hukum internasional, peran yang dimainkan oleh LSM-LSM begitu penting dalam bantuan kemanusiaan di lapangan.

\section{${ }^{4}$ lbid.}

${ }^{5}$ Draft Awal "Rencana Rehabilitasi dan Rekonstruksi Masyarakat Aceh dan Sumatera Utara R3MAS", (28 Februari 2005).

"Lihat Jawahir Thontowi, "Urgensi Peraturan Hukum Bagi Bencana Alam", dalam Hukum dan Bëñ́àna Alam, (Yogyakarta, JICA - FH Ull, 2003).

${ }^{7}$ Kompas, 19 Januari 2005. 
Bahkan suatu negara berdaulat tidak mungkin saat ini menolak relawan asing untuk memberikan bantuan kemanusiaan. Termasuk, bagaimana caranya menyeleksi LSM kemanusiaan; pendelegasian kewenangan mengurus pengungsi, termasuk berbagai aktivitas perlu adanya koordinasi. ${ }^{8}$

Dengan demikian, secara umum penyebab bencana yang selalu mengancam umat manusia di belahan dunia manapun tidak terlepas dari bencana akibat ulah manusia (ManMade Disaster, atau Humanitarian Disaster), bencana akibat alam (Natural Disaster) dan bencana gabungan (Complex Disaster). Dalam tulisan ini akan dilihat tentang bencana alam sebagai penyebab dan ancaman kehidupan umat manusia dan bagaimana masyarakat internasional menaruh perhatian yang cukup terhadap fenomena bencana alam tersebut.

\section{Bencana Alam Dalam Hukum Internasional}

Setelah melihat fenomena bencana dan ancaman yang ditimbulkannya, maka kesedaran masyarakat secara internasional dan nasional mengakui pentingnya pengaturan secara komprehensif. Bilamana hukum internasional, selama ini banyak membahas bencana yäng disebabkan oleh peperangan akibat perbedaan kepentingan antara negara, maka dewasa ini bencana alam jauh lebih menjadi ancaman umat manusia yang lebih problematis. Sehingga masyarakat internasional tidak dapat berpangku tangan. Pantaskah kita menempatkan alam sebagai common enemy karena menimbulkan ancaman. Ataukah alam sebagai mitra makro kosmos yang harus dipahami secara utuh dan harmonis dalam interaksinya.

Dalam kaitannya dengan upaya pengaturan dan penanganan bencana alam dengan organisasi internasional, the Office of the United Nations Disaster Relief Co-ordinator (UNDRO) yang didirikan pada tahun 1971, organisasi ini memiliki peran yang sangat penting. Bahkan pada tahun 1984 UNDRO telah berupaya untuk merancang sebuah Konvensi yang ditujukan bagi pemberian bantuan yang bersifat emergensi. Dalam Preambule Draft Konvensinya dinyatakan bahwa 'the international community has willingly rendered assistance in individual cases of disaster and continues to do so whenever necessary". Di samping itu, program bantuan makanan yang dikoordinasikan oleh WFP (World Food Program) pun sangat aktif berperan dalam pendistribusian bantuan kemanusiaan. Penggantian the Department of Humanitarian Affairs dengan sebuah Office for the Co-ordination of Humanitarian Affairs (OCHA) di PBB pun ditujukan untuk menguatkan peran $\mathrm{PBB}$ sendiri dalam perihal pemberian bantuan kemanusiaan.

Selain PBB, organisasi antar pemerintahan lain seperti Uni Eropa, the North Atlantic Treaty Organization, (NATO) dan ASEAN terlibat dalam penanganan persoalan pemberian. Bahkan, Uni Eropa memiliki lembaga khusus, the European Community Humanitarian Assistance, yang melaluinya Komisi Eropa mengalokasikan dua juta euro untuk membiayai program yang djjalankan oleh lembaga humaniter bagi korban-

${ }^{8}$ Umumnya para pakar sepakat bahwa fenomena pengungsi tidak mungkin dapat diselesaikan oleh negara. Kehadiran organisasi non-pemerintah sebagai mitra pemerintah menjadi sangat penting. Lihat Roberta Cohen and Francis M, Dengmasses in Flight: The Global Crisis Displacement of Internally, 1998, hlm. 187.

${ }^{9} \mathrm{lbid}$. 
korban akibat gempa bumi di Afganistan pada Februari 1998.

Sedangkan dalam kaitannya dengan peran INGOs perlu disebut dua lembaga terkemuka, Palang Merah internasional (ICRC) dan Médecins Sans Frontièrs (MSF). ICRC dalam the Principles and Rules-nya yang diamandemen pada konferensi internasional ke-26-nya menyatakan apabila ICRC memiliki suatu kewajiban fundamental untuk menyediakan relawan terhadap korban-korbän "a fundamental duty to provide relief to all disaster victims". Sementara itu MSF telah aktif memainkan perannya sebagai spesialisasi dalam pemberian bantuan yang bersifat medis.

Dengan demikian, hak atas humanitarian assistance sebagai "hak" yang nyata akibat bencana alam, maka dituntut untuk hadirnya praktik yang seragam dan meluas dari negaranegara terhadap hak yang dimaksud: Akan tetapi, dengan telah terjadinya "modernisasi", maka bantuan atas korban bencana tidak sebatas dari negara, melainkan juga meliputi organisasi intemasional yang bersifat intergovernmentaldan subjek hukum internasional yang tergolong.ke dalam non-state actor.

\section{Kewajiban Masyarakat Internasional}

Dalam dua tahun terakhir ini, Majelis Umum PBB telah berkali-kali mengeluarkan resolusi tentang pencegahan dan penanggulangan bencana alam. Misalnya, pertama, resolusi yang diadopsi oleh Majelis Umum PBB №. 58/214 tentang Strategi Internasional untuk Penanganan Bencana (International Strategi for Disaster
Reduction) 23 Desember 2003. Sikap PBB tersebut menunjukkan ada keserasian dan kepedulian yang mendalam terhadap bencana alam.

Resolusi tersebut mengamanahkan antara lain: "mendorong masyarakat internasional untuk menyediakan sumber bantuan keuangan yang diperlukan terhadap Badan atau Yayasan' 'Dana untuk menyediakan berbagai keperluan ilmiah, teknis, kemanu-siaan, dan baik antara institusi yang terkait atau tidak untuk menekan bahaya yang ditimbulkan oleh bencana (19)". Secara khusus, PBB merekomendasikan untuk mengalokasikan dana yang memadai dan sumber administrasi, dan juga Sekretaris Jenderal untuk menga-jukan usulan pada Majelis Umum PBB, khu-susnya menyiapkan konferensi dunia 'tentang penanggulangan bencana di bawah topik "Lingkungan dan Pembangunan Berkelanjutan": ${ }^{10}$

Kedua, Resolusi Majelis Umum PBB $27^{\circ}$ Februari 2004 tentang Bencana Alam dan Ancaman Bahayanya (Natural Disaster and Vulnerability), yang diputuskan dalam konferensi dunia 26 Agustus - September 2002 di Johanesberg, Afrika. Beberapa petunjuk yang terkait dengan penanggulangan bencana alam antara lain:

1) Mendorong masyarakat intemasional untuk terus berupaya mencari jalan ke luar melalui kerjasama termasuk bantuan tèknis, mengawasi pengaruh negatif dari bencana alam, termasuk yang disebabkan oleh cuaca yang sangat luar biasa, termasuk menggalang kerjasama antara bangsa dalam mengurangi akibat-akibat bencana alam:"

${ }^{10}$ General Assembly, Resolution Adopted by The General Assembly $581 / 214$, International Strategy for Disaster Reduction $78^{\text {In }}$ plenary meeting, 23 December 2003. 
2) Mendorong pemerintah untuk menetapkan suatu kerangka kerja nasional yang efektif untuk mengurangi akibat bencana dan untuk memperkuat sistem penanggulangan jika sebelumnya telah tersedia.

3). Mendorong pemerintah untuk kerjasama dengan sistem PBB dan organisasinya untuk memperkuat kemampuan fisik dalam penanggulangan bencana alam di wilayah yang sangat rentan, agar mereka dapat menanggulangi terhadap sekitar sosial, ekonomi, dan mendorong mereka kerjasama dari bantuan bagi negara-negara ketiga."

Indonesia juga pemah menjadi tuan rumah, Konferensi Tingkat Tinggi Tsunami Sumit, pada tanggal 6 Januari 2005. Pertemuan tersebut dihadiri oleh Sekjen PBB, Kofi Annan, Menlu AS Collin Powel dan juga dihadiri oleh puluhan negara-negara ASEAN, termasuk Lembaga Keuangan Internasional. Bahkan dalam suatu konferensi pers, di New York, PBB menyebutkan, oleh karena banyaknya negara yang menjadi korban bencana, PBB akan mengoperasikan biaya untuk bantuan kemanusiaan paling besar mencapai trilyunan dolar. ${ }^{12}$

Daları pertemuan tersebut dibahas tentang kesanggupan negara-negara donor dan kesiapan negara-negara penerima untuk mematuhi syarat-syarat yang disepakati. Bahkan pertemuan Kyoto, tergolong yang paling besar pasca tsunami, meskipun dipandang tidak berhasil dan memuaskan. Konsekuensi yang tidak dapat dicegah dari bencana alam yaitu lahirnya gelombang pengungsi domestik, yang menjadi tanggungan dan beban suatu negara.
Konferensi internasional tentang pengurangan bencana, World Conference on Disaster Reduction diselenggarakan di Kobe, Kyoto, Jepang, 18-22 Januari 2005. Dalam Konferensi tersebut ada lima aspek yang dijadikan agenda penting, terkait dengan perencanaan strategi untuk aksi penyelamatan dunia. (srategy and plan of action for a sever world). Dalam kesimpulannya direkomendasikan lima persoalan penting.

Pertama, peran pemerintah '(govemance) yang harus ditingkatkan dalam penaggulangan bencana ke depan yaitu upaya organisasi, peraturan hukum dan kebijakan kerangka kerja (organizational, legal and polyce frameworks). Kedua, identifikasi resiko, perhitungan, monitoring dan peringatan dini. Ketiga, pengetahuan manajemen dan pendidikan (knowledge management and education). Keempat, upaya penurunan faktor-faktor yang menimbulkan resiko (redusing underlying risk factor). Kelima, kesiapan untuk melakukan respon dan pemulihan yang efektif (peparadness for efective responess and recovery). ${ }^{13}$ Dari kelima persoalaan tersebut harus benar-benar dijadikan muatan materi UUPBA, yang sekaligus juga harus mengamanahkan adanya kewajiban bagi negara untuk menanggulangi bencana alam termasuk korbannya.

\section{IDP's Sebagai Korban Bencana}

Pengungsi domestik berasal dari kata Inggris Intemaly Displaced Person(IDP's). Meskipun IDP's timbul oleh penyebab yang berbeda, pengungsi dalam bahasa Indonesia dimaksudkan sebagai IDP's. Pengungsi (refugee) selalu dimaknai

\footnotetext{
"General Assembly Natural Disaster and Vulnerability 58/215 27 February 2004.

${ }^{12}$ Lihat Kompas 29 Desember $2005 \mathrm{hlm}$. 11 dan Kedaulatan Rakyat KTT Tsunami diselenggarakan di Jakarta, 6 Januari 2005, hlm.1.

${ }^{13}$ United Nation: World Conference on Disaster Reduction, Kobe, Kyoto, Japan:
} 
sebagai gelombang manusia yang melarikan diri dari suatu tempat atau negara ke negara lain, dengan alasan mereka sedang mencari rasa aman dan selamat. Mereka tidak mungkin tinggal ketika perasaan aman dan kekacauan politik mengusik keselamatannya (Pasal 1 Konvensi Pengungsi 1951). Namun, saat ini konsep pengungsi telah berubah seiring dengan runtuhnya perang dingin diakhir tahun 80-an. Pengungsi domestik (Internally Displaced Person) atau IDP's seperti dialami masyarakat Aceh dan Nias saat ini telah disejajarkan statusnya dengan pengungsi internasional (refugee).

Mensejajarkan status dan hak refugee dan IDP's dalam Pasal 1 Konvensi tersebut merupakan evolusi konsep yang lebih luas (evolving concept). Jerzy Sztucki, pakar hukum internasional, dalam karyanya, Who is Refugee, mengakui bahwa definisi pengungsi dalam Pasal 1 Konvensi Internasional 1951 telah berubah maknanya. ${ }^{14}$ Perasaan takut dan terancam yang menjadi penyebab seseorang melarikan diri ke luar negeri adalah dipengaruhi oleh kekuatan pertarungan ideologi Barat kapitalis dengan sosialis komunis.

Kedudukan dan status pengungsi akibat bencana alam atau bencana kemanusiaan tidak terlepas dari prinsip-prinsip dan peraturan yang tersedia dalam Konvensi Internasional tentang Pengungsi, UNHCR 1951. Semula amanah fundamental dalam konvensi tersebut ditujukan pada pengungsi internasional. Seseorang yang mengalami rasa takut mendalam karena tersiksa atas alasan ras, agama, nasionalitas untuk melari- kan diri ke negara lain. Ternyata dalam aplikasinya mengalami evoluasi, sehingga pengungsi yang menderita dan terancam bukan sekedar pindah atau kembali ke tempat asal berbeda negara. Dalam satu negara itupun dimungkinkan seseorang yang pindah temipat karena alasan-alasan diatas, termasuk bencana alam dapat menyandang status pengungsi. ${ }^{15}$

Saat ini, ancaman bahaya yang menyebabkan orang-orang melarikan diri, pindah ke tempat lebih aman dan menjadi pengungsi bukan saja disebabkan karena perang, atau kerusuhan sosial. Melain!kan juga karena peristiwa bencana alam. Jumlah pengungsi atau IDP's di Aceh sekitar 450.000 dan juga ribuan pengungsi di Nias tetap merupakan subjek yang harus ditolong oleh relawan termasuk peran UNHCR dan IOM. Kehadiran UNHCR dan relawan asing masih sangat diperlukan dalam mengkoordinasikan program bantuan, baik untuk tenda darurat, kesehatan, wanita, anak-anak dan orang tua.

- Bilamana tidak secara tegas diformulasikan aturannya, maka setiap kelalaian tersebut akan berakibat timbulnya pengaduan. IDP's atas hak-hak dasar mereka dan juga beban anggaran akan selalu tidak terpenuhi. Mekanisme pengaduan ini tentu diatur dalam Protokol PBB (The Relevance of the Guiding Principle on Internal Displacement to the Individual Complanints of Human Rights Treatress in the United Nations System). ${ }^{16}$ Secara ekonomis, resiko akibat bencana telah menjadi ancaman konkrit, APBN akan senantiasa gagal dalam menanggulangi.dan

${ }^{14}$ Jerzy Sztucki, Who is Refugee, (Website ICRC 1998), hlm. 51-80

${ }^{15}$ Lihat Jean Yres Cavalier, The Geneva Refugee Definition, 2000, hlm. $31-54$

${ }^{16}$ Lihat September 20-23, 2000. Viena, Austria (Joan M. Fitzparticle (ed) 2001), hlm. 545 
menangani akibat bencana, jika persoalan IDP's tidak diformulasikan secara khusus dalam UUBA.

\section{Bantuan Kemanusiaan}

Bantuan kemanusiaan semula merupakan ketentuan hukum kebiasaan (customary rules). Sedangkan bantuan kemanusiaan dalam konteks peperangan, khususnya korbankorban akibat peperangan diatur dalam Konvensi Palang Merah Internasional, ICRC (International Convention Redcross) 1949. Konvensi tersebut umumnya dipergunakan untuk memberikan bantuan atas korbankorban yang terjadi akibat peperangan atau perang sipil. Saat ini timbul subjek hukum di luar kondisi peperangan, yaitu bantuan kemanusiaan akibat bencana alam.

Dalam konteks bencana alam, maka istilah yang tepat dipergunakan yaitu, bantuan kemanusiaan (humanitarian assistance). Dalam perspektif HAM, bantuan kemanusiaan bukan sekedar ketentuan hukum lunak, (lex feranda) tetapi saat ini telah mencapai status hukum yang dapat dipaksakan (lex lata). Karena itu, bilamana ada negara yang menolak bantuan kemanusiaan dapat dipandang sebagai kejahatan internasional.

Sedangkan bentuk kedua, bantuan kemanusiaan yang disediakan untuk korbankorban akibat peperangan dikenal dengan istilah intervensi kemanusiaan. Sejak lebih dua dasawarsa, intervensi kemanusiaan (humaniotarian intervension) yaitu bantuan kemanusiaan tidak sekedar melaksanakan tugas memberi- kan pertolongan dan bantuan kemanusiaan dilakukan oleh militer asing, melainkan dengan maksud menjaga dan melindungi pihak-pihak yang bertikai. Kebolehan militer terlibat dalam bantuan kemanusiaan tersebut telah dijamin oleh Pasal 3 dari Konvensi Genewa Protokol II. Pasal tersebut dapat diterapkan kepada negaranegara pihak terhadap kasus dan keadaan bukan persengketaan militer internasional (nonintemational amed conflict). ${ }^{17}$

Sejak terjadinya perang sipil di Bosnia Herzekoviena 1992, adanya kesediaan dari relawan-relawan untuk memberikan perto-iongan secara sukarela, dan penuh kepedulian, dilakukan secara independen, non-diskriminatif, dan penuh hormat serta bersikap toleran. Tugas relawan, baik asing maupun dalam negeri harus mematuhi code of conduct of humanitarian assistance.

Dalam kaitannya dengan hal tersebut, sengketa militer antara kaum pemberontak dengan pemerintah yang sah atau juga bencana alam yang mengganggu keamanan publik bantuan kemanusiaan dengan aktor militer dibenarkan. Ian Brownlie memperkuat argumen tersebut di atas dengan mengutip Piagam Sosial Eropa (European Social Charter 1961) Pasal 31 (1) bahwa mereka yang harus mendapatkan perlindungan dalam masyarakat demokratis: perlindungan atas hak-hak dan kebebasan, dan perlindungan terhadap kepentingan umum (public interest) keamanan nasional (national security) kesehatan umum (public health) dan moralitas. ${ }^{16}$

${ }^{17}$ Lihat lebih lanjut dalam Walter Kalin, Guiding Principles on Intemal Displacement. Annotationsl; Studies in Transnational Vrgal lpolicy. No 32. The Amercian Society of International Law, (The Brooking Intitution, Project on Internal Displacement. 2000), him. 258. 
Selain itu, bantuan kemanusiaan dilakukan oleh kelompok masyarakat sipil termasuk lembaga-lembaga keagamaan. Sedangkan intervensi bantuan kemanusiaan dilakukan oleh militer dengan adanya unsur tekanan dan paksaan. Kedua bentuk bantuan kemanusiaan umumnya diberikan pada bencana-bencana yang diakibatkan oleh alam. Sementara, intervensi kemanusiaan disediakan pada umumnya hanya untuk menolong korban-korban bencana akibat peperangan atau perang saudara, atau konflik bersenjata yang dilakukan secara kolektif, melalui keputusan DK-PBB. Misalnya, intervensi bantuan kemanusiaan diterapkan dalam kasus Timor Leste, ketika terjadi peralihan kekuasaan dari Indonesia di bawah payung PBB tahun 1999.

Kedua model bantuan kemanusiaan ini cukup relevan dipergunakan dalam kasus bencana Aceh. Selain di Aceh diperlukan militer untuk mencegah genjatan senjata, antara TNI dengan GAM, juga dapat dipergunakan untuk melakukan evakuasi dan rehabilitasi berbagai kerusakan fisik. Seperti, bangunan-bangunan pemerintah, perbaikan jalan, dan juga membangun jembatanjembatan. Tanpa bantuan TNI amatlah berat proses pemulihannya. Ratusan jembatan mustahil dapat dibangun dengan hanya menggunakan kekuatan relawan sipil yang serba penuh keterbatasan. Namun, dalam faktanya justru bantuan kemanusiaan yang menjadi perhatian utama.

Mengingat praktik intervensi kemanusiaan mengandung isu begitu sensitif, alasan penggunaan kekuatan militer perlu bukti yang meyakinkan..$^{19}$ Christine Gray menyebutkan beberapa parameter. Misalnya, adanya situasi yang memerlukan bantuan kemanusiaan yang luar biasa. Adanya pemulihan yang dilakukan secara darurat. Tidak ada alternatif praktis untuk menggunakan penekanan sebagai upaya penyelamatan manusia. Paksaan harus dipergunakan secara layak sesuai dengan maksud dan tujuan bantuan kemanusiaan. Intervensi kemanusiaan harus dilakukan sesuai dengan hukum internasional. Kemudian tindakan militer dipergunakan harus dimaksudkan sebagai upaya mencapai tujuan, dan dilakukan secara liclektif.

Dengan demikian, bantuan kemanusiaan merupakan kewajiban internasional baik bagi bencana yang disebabkan oleh alam maupun oleh karena pertikaian senjata. Dalam praktiknya saat ini, bantuan .kemanusiaan disediakan merupakan program PBB yang melibatkan banyak organisasi dunia, baik organisasi pemerintahan atau non pemerintahan. Akibatnya, negara-negara pihak bukan sajatidak dapat menolak bantuan asing. Selebihnya, negara wajib melayani pekerja kemanusiaan secara adil.

\section{Urgensi UUPBA di Indonesia}

Letak Indonesia dihadapkan pada dua kondisi yang tak terpisahkan. Di satu sisi, wilayah Indonesia menyimpan kekayaan alam yang sangat potensial, oleh karena secara geografis terletak di daerah tropis yang memberi berkah kesuburan. Di sisi lain, berada dalam wilayah yang rentan bencana

${ }^{18}$ Lihat lan Brownlie (ed), Basic Documents on Human Rights, (Oxfrod: Clarendon Express. 1971), hlm. 381.

${ }^{19}$ Lihat Christine Gray, The Use of Force and The International Legal Order, (Malcolm. D. Evan 2003), him. 597. 
karena ancaman klimatologis dan geologis oleh karena tiga lempengan raksasa. Lempengan Australia yang bergerak ke utara dan lempengan pasifik yang bergerak ke Barat, dan lempengan eurasia yang relatif stabil. Situasi tersebut acapkali memunculkan ancaman bencana berupa longsor, gempa dan letusan gunung berapi, banjir dan juga termasuk ancaman tsunami. Peristiwa bencana alam tersebut, telah menimbulkan kerugian bagi korban-korban manusia, harta kekayaan, termasuk hancurnya kondisi alam..$^{20}$

Peristiwa bencana yang terjadi tanggal 26 Desember 2004, tercatat 8,7 skala richter tergolong bencana yang terbesar abad ini. Sehingga negara-negara di sekitar Asia yang turut menderita yaitu India, Srilangka, Muangthai, Afrika Selatan, Malaysia dan Indonesia. Indonesia yang terletak antara pintu gerbang lautan Hindia dengan laut Pasifik, telah menuai korban yang begitu luar biasa. Sebagaimana tercatat ratusan ribu korban tewas dan kerugian harta kekayaan lainnya. Hal ini mendorong pemerintah untuk berkabung nasional. dengan memasang bendera setengah tiang selama tiga hari berturut-turut.

Kebutuhan akan payung hukum tentang pencegahan dan penaggulangan bencana alam akhir-akhir ini, telah menjadi tema nasional yang cukup menarik. Urgensi Undang-Undang Penanggulangan Bencana Alam (UUPBA) dirasakan mendesak, terutama sejak peristiwa 26 Desember 2004, bencana Tsunami di Aceh. Angggota-anggota DPR RI, seperti Teras Narang, (24-1-2005) dan
Ketuanya Agung Laksono menghendaki adanya UUPBA segera dibuat. Tidak ketinggalan, pendapat yang sama disampaikan Menteri Sosial, M. Bachtiar Khamsah dan M. Yusuf Asy'ari, Menteri Perumahan Rakyat. ${ }^{21}$

Wacana tentang UUPBA bukan persoalan baru. Fakultas. Hukum Universitas Islam Indonesia (UII) telah menyelenggarakan Seminar Nasional, yang bekerjasama dengan JICA-Jepang 16 April 2002. Seminar tersebut, menyetujui adanya UUPBA mengingat indonesia belum memiliki sistem peraturan hukum terkait dengan bencana. Sehingga kehadiran UUPBA tidak sekedar merupakan payung hukum bagi penanggulangan semata, melainkan harus diarahkan pada upaya mendorong tumbuhnya kesadaran masyarakat dalam mencegah dan menanggulangi ancaman bencana alam.

Meskipun 150 RUU telah dijadikan Program Legislasi Nasional (Prolegnas) oleh DPR RI, tidak berarti UUPBA luput dari pembicaraan DPR, DPD dan pemerintah tahun ini. Kehadiran UUPBA dalam kondisi Indonesia yang selalu terancam bencana menjadi sangat bermakna. Dr. Puji Pujiono, Sekretaris Jenderal Masyarakat Penanggulangan Bencana Indonesia telah mendiskusikan dengan Panitia Kerja RUU Penanggulangan Bencana DPR di Jakarta 30 Maret 2005.22 Pembuatan UUPBA tersebut diperlakukan agar dapat memperjelas tugas dan wewenang serta tanggungjawab pemerintah. Tidak kalah pentingnya pengaturan terhadap relawan domestik dan asing yang terlibat dalam bantuan kemanusiaan. ${ }^{23}$

${ }^{20}$ Sarwidi, Op. Cit.

${ }^{21}$ Seminar Nasional, "Pemulihan Aceh Pasca Bencana Demi Keutuhan NKRI", (diselenggarakan oleh Ikatan Alumni UII di Jogjakarta, tanggal 9 Maret 2005). 
Sekiranya kerangka dasar hukum internasional dan pendekatan konstitusional dipandang relevan, maka belumlah cukup untuk dijadikan dasar yuridis bagi pencegahan dan penanggulangan bencana alam. Ketiadaan sistem peraturan hukum bencana alam yang terpadu menjadi penyebabnya. Sehingga tidaklah berlebihan jika Fujisawa Kazunori menyimpulkan bahwa "selama ini tidak terdapat sistem hukum yang bermanfaat untuk penanggulangan bencana di Indonesia ".24 Indonesia tidak mengatur secara rinci mengenai upaya pencegahan dan penanggulangan bencana alam menjadi tantangan dan sekaligus peluang bagi

- hadirnya suatu perangkat Undang-Undang Bencana Alam.

Pentingnya UUPBA juga terkait dengan frekuensi bencana alam yang tidak mudah diduga menyadarkan kita untuk mempersiapkan berbagai instrumen. Baik instrumen tersebut berbentuk kasar (hard ware) maupun lunak (soft ware). Bahkan Ketua MPR, Hidayat Nurwahid mengusulkan agar pemerintah menyusun Komisi khusus, seperti KPK. Sedangkan Editorial mengusulkan agar DPR segera menyetujui anggaran pembelian peralatan deteksi gempa yang dimiliki Thailand. ${ }^{25}$ Dua negara yang telah menerapkan sistem peringatan dini (early waming system) melalui alat deteksi di laut yaitu India dan Thailand.

Namun, tidak kalah pentingnya adalah instrumen hukum yang dapat dijadikan acuan utama bagi persoalan bencana. Sebagai perbandingan, Jepang tergolong negara,yang rentan dengan bencana alam, tetapi korban dan kerugian yang ditimbulkannya selalu dapat ditekan. Upaya untuk meminimalisir korban di Jepang salah satu faktor antara lain fungsi UU SABO. Suatu sistem peraturan hukum yang dapat,mencegah timbulnya bencana alam dan menanggulanginya akibat sedimentasi lumpur dari sungai, tanah longsor dan runtuhnya lereng gunung. SABO LAW di Jepang telah berumur satu abad. Saat ini telah dilengkapi dengan lahirnya UU Pencegahan Tanah Longsor (1962). Pencegahan Bencana Runtûtinya Lereng-Lereng Curam (1971), dan UU tetang Pencegahan Bencana Pengendapan Tanah. ${ }^{26}$ Seorang pakar hukum bencana Jepang Fujisawa Kazunori, menegaskan perlunya biaya yang mahal bukan sekedar untuk membuat undang-undang, melainkan juga untuk biayai pemeliharaan dan pencegahan yang berkelanjutan.

Kebutuhan pemerintah $\mathrm{Rl}$ untuk membuat UUPBA bukan saja didukung oleh faktor geologis dan ontologis, namun pengaturan terhadap fasilitas modern, peraturan hukum dan SDM menjadi sangat penting.

\section{Substansi Hukum Bencana Alam}

Meskipun fenomena bencana alam tidak mudah dikelompokkan pada hukum publik maupun hukum privat, timbulnya korban-

${ }^{22}$ Lihat Kedaulatan Rakyat, 7 April 2005, Diperkuat oleh diskusi antara (FH UII dengan anggota Dewan Perwakilan Daerah (DPD) di Jogyakarta 6 April 2005).

${ }^{23}$ Lihat Kompas, Kamis 31 Maret 2005, "RI Butuhkan UU Penanganan Bencana".

${ }^{24}$ Fujisawa Kazunory, dalam Jawahir Thontowi, Hukum dan Bencana Alam, (JICA - FH UII, Yogyäkarta 2002), hilm. 151

${ }^{25}$ Tempo, 20 Maret:2

${ }^{26} \mathrm{lbid}$. 
korban menuntut pemerintah untuk membuat UUPBA. Persoalannya adalah esensi apakah yang harus terumuskan di dalamnya. Suatu ketentuan hukum, asas-asas dan petunjuk atau syarat-syarat yang menegaskan bahwa negara dan masyarakat bertanggungjawab atas bencana yang menimpa nasib masyarakat. Termasuk upaya-upaya pencegahan dan peningkatan kesadaran masya-rakat akan bencana alam.

\section{Konsep Bencana dan Penyebabnya}

Materi utama yang dijadikan kajian, dalam perumusan konsep-konsep hukum sehingga menjadi jelas dan pasti. Bencana dipandang sebagai ancaman keamanan dan keselamatan manusia. Jenis-jenis bencana, seperti tanah longsor, kebakaran, dan tsunami. Upaya-upaya yang wajib dilakukan masyarakat baik bersifat pencegahan (preventif) maupun. penanggulangan (mitigation), dan pertolongan tidak dapat dilupakan. Sehingga masyarakat akan selalu peduli. Penentuan kategori bencana bersifat nasional dan lokal menjadi sangat penting karena terkait dengan model penanggulangan dan juga penentuan anggaran yang wajib dilaksanakan oleh pemerintah.

\section{Sistem Peringatan Dini (System Early Warning)}

Sistem peringatan dini (system early warning) menjadi sangat penting ditetapkan. Hal ini tidak saja terkait dengan perlunya alokasi dana bagi pembelian instrumen modern bagi alat tekhnologi deteksi dini. Tentu saja selain harganya tidak murah, juga model pemeliharaan dan orang-orang yang ditugaskan perlu dilindungi oleh peraturan hukum yang jelas. Syarat-syarat kapan suatu peringatan dini dapat dikeluarkan atau diumumkan. Serta tanda tanda apakah agar peringatan dini dapat dipercayai masyarakat. Perlunya ada perbedaan antara tanda peringatan dini bencana banjir, tanah longsor, dan bencana Tsunami.

\section{Hak Korban Untuk Mendapatkan Pertolongan}

Hak korban untuk memperoleh bantuan termasuk hak dasar yang fundamental bagi negara-negara yang telah meratifikasi Konvensi Hak-Hak Dasar Politik dan Ekonomi, ICSER (International Covenant for Social, Economics and Cultural Rights) penolakan berakibat penjatuhan sanksi. Konvensi ini telah diadopsi oleh Majlis Umum PBB, 16 Desember 1966. Secara khusus, hak yang diperlukan dan wajib ditunaikan oleh negara adalah jaminan sosial (social security) mencakup perlindungan terhadap keluarga, Ibu dan anak-anak, jaminan standar kehidupan yanglayak, seperti makanan, pakaian, perumahan, kesehatan fisik dan mental, pendidikan, dan kebudayaan. Pemerintah suatu negara yang tidak mampu menunaikan kewajiban tersebut dipandang melanggar dan karena itu harus mempertanggungjawabkannya. ${ }^{27}$

Pasal 41 UU No 39/1999 tentang Hakhak Asasi Manusia, menentukan: "Setiap warga negara berhak atas jaminan sosial, yang diartikan sebagai setiap warga negara mendapatkan jaminan sosial". ${ }^{28}$ Bahwa bantuan kemanusiaan bukan sekedar norma

${ }^{27}$ Alston dalam International Human Right in Conteks : Law, Politics and Moral, Henry J. Steiner \& Philip Alston, (Oxpord Clarendon Press, 1996), him. 263-264. 
hukum yang lemah (lex feranda), melainkan telah menjadi norma hukum yang mengikat.

\section{Media Informasi dan Monitoring}

Untuk menetapkan adanya keadaan bahaya dan perlunya peringatan dini, diperlukan adanya pengumpulan data dan informasi yang cukup lengkap dan akurat. Pusat informasi dan monitoring inilah yang secara khusus dan bekerja penuh waktu, agar tanda-tanda bencana tidak luput dari pantauannya. Begitu pula pusat informasi akan berfungsi mengumpulkan data-data dalam keadaan darurat dan pasca bencana. Sehingga korban tewas, luka-luka, dan selamat perlu segera dilaporkan. Agar periolongan logistik, kesehatan, dan juga pemukiman segera dapat dirumuskan menjadi suatu kebijakan yang tepat. Terutama ketika waktu, tanggap darurat dan rehabilitasi pasca bencana perlu segera di buat, sehingga anggaran biaya dapat dibuat secepat mungkin, dengan penuh kepastian.

\section{Tanggung jawab Negara}

Yang menjadi persoalannya adalah, siapa yang harus bertanggungjawab untuk menjaga keamanan, keselamatan, dan melindungi kesejahteraan masyarakat. Dalam hal ini, pakar lingkungan seperti Goldie (1986:185) menegaskan bahwa, upaya negara untuk menjaga keamanan, keselamatan, dan melindungi kesejahteraan masyarakat, dipandang sebagai tanggung jawab negara ke dalam (internal responsibility). ${ }^{29}$ Tugas dan fungsi negara yang penting yaitu untuk menciptakan kebahagiaan masyarakat, sebagai kepentingan umum bonum publicum atau common good.

Marsudi Triatmodjo, menegaskan pentingnya parameter untuk menentukan ada tidaknya pertanggungjawaban negara. Parameter pertanggungjawaban harus mengandung kegiatan (action), akibat (effect), tempat (Space), sumber penyebab (main causes), dan korban (Victims). Keempat unsur tersebut telah cukup memadai untuk menimbulkan adanya pertanggungjawaban negara bilamana negara tidak menjalankan kewajiban secara memadai. Kelalaian yang dibuat tersebut kemudian dapat mengganggu kepentingan umum (public interrst) dan menimbulkan ancaman bahaya bagi masyarakat dan lingkungannya. ${ }^{30}$

Hubungan antara bencana alam dan tanggung jawab negara tercermin dalam Alinea IV Pembukaan UUD 1945. "....kemudian daripada itu untuk membentuk suatu pemerintahan negara Indonesia dan seluruh tumpah darah". Ketentuan tersebut menunjukkan adanya kewajban negara untuk melindungi segenap masyarakat (state legal obligation). Jabaran lebih lanjut dapat dirujuk pasal 30 tentang pertahanan dan keamanan, dan pasal 33 dan 34 tentang sistem ekonomi dan jaminan kehidupan bagi fakir miskin dan anak-anak terlantar dipelihara oleh negara.

\section{Kewajiban Masyarakat Mematuhi Hukum}

Sepertihalnyamasyarakatyang tidakmematuhi

${ }^{28}$ Lihat Rohan J. Castle dan Andrian T.L.Chun (1992, hlm.51). $\therefore$

${ }^{29}$ Lihat Goldie, Transpronties Pollution-from Concepts of Liabillity to Administrative Concillition, -1986 , hlm. 185.

${ }^{30}$ Marsudi Triatmodjo, Hukum dan UU Bencana Alam, 2001, Him. 59. 
peraturan hukum tentang lingkungan hidup dan tata kota atau perizinan, sesuatu bangunan juga dapat dibebani pertanggungjawaban hukum. Meskipun kerangka teoritik tersebut dipergunakan untuk persoalan lingkungan, tetap relevan dipergunakan untuk dikaitkan dengan peristiwa bencana alam dan pertanggungjawaban mengingat pelanggaran terhadap UU No 23 tahun 1997 tentang Pelestarian Lingkungan Hidup. Dalam ketentuan pasal 5 ayat (3) UUPLH tahun 1997 ditegaskan, "bahwa setiap orang berkewajiban menjaga dan melestarikan lingkungan dari penurunan kualitas lingkungan. Khusus bagi para pelaku usaha diwajibkan mematuhi AMDAL sebagai persyaratan yang mutlak harus dikuti". ${ }^{31}$

Agar tanggung jawab yang dibebankan pada negara dapat didistribusikan dalam bentuk kewenangan-kewenangan (otoritative againcies), pendekatan hukum administrasi negara menjadi penting. Selain negara memiliki kewajiban untuk memberikan pertolongan, termasuk mengalokasikan anggaran bagi korban, juga sistem pengawasan mutlak diperiukan. Sehingga praktik penyimpangan atas bantuan kemanusiaan yang selama ini didengar dapat segera dicegah.

\section{Peran Pemerintah - TNI \& Polri}

Status SDM yang biasanya terlibat dalam. kondisi-kondisi darurat dan gawat juga sangat prinsip untuk diformulasikan dalam peraturan hukum. Sudah merupakan keniscayaan TNI dan Polri di negara maupun, baik diminta atau tidak, untuk langsung terlibat dalam bantuan kemanusiaan. ${ }^{32}$ Termasuk, bagaimana status dan kedudukan relawan asing dan domestik ketika mereka terlibat dalam bantuan kemanusiaan. Namun, bagaimana dan syaratsyarat apakah yang harus dipenuhi ketika TNI, Polri dan relawan asing diizinkan masuk ke wilayah bencana perlu kejelasan. Hal ini disamakan situasinya dengan keadaan darurat sipil seperti tercantum dalam pasal 11 ayat (1) UUD 1945, yang juga diperkuat dengan UU No 3 tahun 1945.

Menurut UU/Perpu No. 23/1959 tentang keadaan bahaya, mengenai tiga kualifikasi keadaan, yaitu; 1) Tertib Sipil; yaitu keadaan aman tenteram dan terkendali. Pemerintah sepenuhnya di tangan sipil seperti yang terjadi sekarang umumnya di Indonesia. 2) Darurat Sipi; keadaan aman terganggu oleh suatu bahaya dan instansi sipil, konkritnya Polri, tidak mampu mengatasinya. Dalam keadaan demikian, pemerintah masih ditangan sipil, namun kekuatan militer mulai diperbantukan untuk menyingkirkan bahaya itu secepatnya. 3) Darurat Militer; terjadi pemberontakan. Keadaan bahaya atau perang dinyatakan oleh Presiden dan Panglima TNI setelah mendengar pertimbangan DPR RI. Pemerintah sepenuhnya di tangan militer. ${ }^{33}$

\section{Legal Advocacy dan Legal Action}

Aspek substantif penting yang terkait dengan penanggulangan bencana alam adalah bantuan hukum (legal advokacy) dan

\footnotetext{
${ }^{31}$ Lihat Saru Arifin, Hukum dan Bencana Alam di Indonesia, HIm. 3

${ }^{32}$ Lihat pasal 11 UUD 1945 tentang Keadaan Ancaman dan dapat diperkuat dengan Undang-Undang Tentang Keadaan Bahaya.

${ }^{33}$ Komisi Konstitusi tentang Perubahan Undang-Undang Dasar Negara RI tahun 1945. HIm. 48
} 
tindakan hukum (legal action). Bantuan hukum wajib disediakan bukan hanya karena korban perlu dibantu untuk memperoleh hak-hak mereka. Tetapi, bantuan-bantuan juga diperiukan bagi pemerintah terutama ketika rakyatnya membangkang untuk tidak mematuhi hukum. Sebagaimana halnya bantuan hukum bagi pemerintah diperlukan ketika masyarakat nelayan di Meulaboh menolak untuk diungsikan ke tempat yang lebih aman (safe areas). Namun, ketika pemerintah gagal dalam menunaikan kewajibannya, masyarakat juga memiliki hak untuk melakukan pengaduan atau gugatan (the right for legal action).

\section{Kebebasan Memilih Tempat Tinggal}

Pemaksaan atas mereka untuk meninggalkan tempat asalnya dapat dengan mudah negara dipersalahkan dari segi hukum hak asasi manusia. Dalam pasal 13 (1) Declarasi Universal HAM, 'dan ICCPR pasal 12 (1) ditegaskan Everyone Lawfuly within the territory of a stale shall, whitin that territory, have the right to liberty of movement and freedom to choose his residance. Bahkan program pemukiman yang dipaksakan kepada mereka akan dipandang pelanggaran terhadap kebebasan berpindah.

Forced allocation to a Particular area following removal, including in the context of villagization programmess or banishmient to arbitary detention to an infrigement of freedom of mevement. ${ }^{34}$

Pengaturan relokasi dan pemukiman bagi korban harus tetap menjungjung tinggi kebebasan menentukan tempat tinggal.

\section{Organisasi Penanggulangan Bencana}

Sebaik apapun materi muatan UU tidaklah akan efektif jika tidak didukung oleh insitusi yang legitimate dan kompeten. Selain terdapat garis dan mekanisme kerja yang jelas juga proses pengambilan keputusan harus menjadi sederhana dan tidak bertele-tele. $\mathrm{Di}$ berbagai negara ASEAN, institusi penanggulangan manajemen bencana alam beraneka ragam. Namun, pada umumnya SDM yang mengisi institusi tersebut langsung diangkat oleh Presiden atau Perdana Menteri. Bahkan di Philipina dan di Thailand, Lembaga Penanggulangan Bencana dilakukan dalam Dewan Koordinasi Bencana Nasional (The National Disster Cordinating Council). Di Thailand, manajemen bencana beradadan dilaksanakan oleh Komisi Pertahanan Sipil Nasional (The Naional Civil Defence Committe). Kamboja, memiliki Komisi Nasional untuk Manajemen Bencana (The National Committe for Disaster Manajemen).

Di Indonesia, juga dikenal Bakornas, (Pusat), Satkorlak (Provinsi) dan Satlak (Kabupaten). Secara parsial diakui bahwa, saat ini instrumen hukum yang ada baru sebatas Keppres No. 3 Tahun 2001, tentang penanggulangan bencana alam dan pengungsi. Hal ini merupakan salah satu putusan kebijakan di luar produk hukum Lembaga DPR. Sehingga, apabila dihadapkan pada skala peristiwa bencana dan kompleksitas persoalan pasca bencana Keppres tersebut sungguh tidak akan berfungsi secara optimal. Tiadanya batasan antara bencana yang dapat menimbulkan dampak serius bagi penaggulangannya, termasuk pengalokasian kewenangan bagi institusi pemerintah pusat

${ }^{34}$ Walter Kalin, Op. Cit HIm. 258 
dan daerah mengharuskan adanya upaya yang lebih sistematis dan komprehensif.

Penelititan yang dilakukan oleh Jawahir Thontowi, yang diselenggarakan oleh IMPRESS bekerjasama dengan JICA tahun 2003, mencatat beberapa kelemahan dari eksistensi peraturan pencegahan dan penanggulangan bencana alam, yang dilakukan oleh BAKORNAS. Setidaknya terdapat lima catatan penting yang membuktikan Keppres No. 3 Tahun 2001 tersebut tidak efektif. Pertama, payung hukum yang tersedia terlalu operasional sehingga tidak mampu mencakup kompleksitas persoalan bencana alam. Kedua, adanya pencampuran penanggulangan bencana antara akibat alam dan akibat ulah manusia yang mestinya dipisahkan. Ketiga, peraturan hukum tersebut tidak memperlihatkan perbedaan antara fungsi efektif dalam waktu darurat (the sence of crisis and emergency), dengan pencegahan dan penanggulangan untuk jangka menengah dan panjang. Keempat, ambigu dalam memberikan kewenangan dan alokasi peran institusi. Struktur BAKORNAS terlalu birokratis sehingga menyumbat penanganan yang cepat dan tanggap darurat. Kelima, peraturan hukum tersebut belum bisa menyesuaikan esensi dan prosedurnya dengan semangat otonomi daerah. ${ }^{35}$

Hasil penelitian tersebut juga diperkuat oleh. Menteri Sosial H. Bachtiar Chamsyah, yang menegaskan bahwa kehadiran Wapres, sebagai koordinator Bakornas menyalahi sistem ketatanegaraan Indonesia. Dalam sistem Presidentil, bukan saja Presiden dan
Wapres berada dalam satu paket, melainkan juga Keppres bukan merupakan sumber hukum sejak adanya reformasi. Itulah sebabnya Keppres tersebut tidak efektif. ${ }^{36}$

Bagaimana mungkin organisasi BAKORNAS yang diamanahkan oleh Keppres akan dapat merespon secara cepat, semen-tara pusat koordinasi tidak jelas. Wakil Presiden menjadi Koordinator BAKORNAS yang harus bertanggungjawab kepada Presiden. Hal ini sungguh ironis dalam sistem pemerintahan Presidentil. Sebab, Wapres tersebut berfungsi sebagai 'ban serep' bagi Presiden yang nota bene juga berada dalam satu paket.

Tiadanya koordinasi yang sistematis diantara instansi pemerintah yang terkait, bukan disebabkan oleh tiadanya aturan, melainkan lebihdisebabkan oleh fakta bahwa Keppres No.3 Tahun 2001 tentang Penanggulangan Bencana Alam dan Penanganan Pengungsi bukan merupakan payung hukum yang layak. Bagaimana mungkin Keppres dapat dijadikan instrumen hukum yang efektif, bilamana esensi dan prosedumya tidak legitimate keberadaannya, baik secara teoritis maupun sosiologis.

Komisi Nasional Penanggulagan Bencana (The National Committee for Natural Disaster Management) harus dibentuk sesuai amanah UUPBA yang kedudukannya independen, sifatnya non-Departemental, langsung berada di bawah komando Presiden, dengan keanggotaan hak dan kewenangan serta tanggung jawab langsung pada Presiden. Kedudukan KNPBA dan struktur organsiasi harus lebih sederhana agar mekanisme

${ }^{35}$ Lihat Jawahir Thontowi, Legal System Related to Natural Disaster in Indonesia, (Jica-IMPRESS, Yogyakarta 2003).

${ }^{36}$ Disampaikan dalam acara Seminar Nasional, Upaya Pemulihan Aceh Pasca Bencana Demi Keutuhan RI, (Diselengarakan oleh IKA UII Yogyakarta, 9 Februari 2005). 
pengambilan keputusan menjadi cepat sesuai kebutuhan. Pusat koordinasi sangat tegas sehingga pengaturan kerjasama antara departemen terkait dapat dilakukan secara cepat dan terkoordinasi secara terpadu. Konsekuensinya, program perencanaan, dan aksi dalam pencegahan, penanggulangan dan aksi dikoordinasikan oleh KNPBA.

\section{Pendekatan Terhadap UUPBA}

Aspek lain yang perlu dijadikan catatan khusus adalah status kekhususan RUUBA dalam penerapannya. Kekhususan inilah yang hendak dijadikan pembeda dengan RUU yang lain yang senantiasa dibuat untuk kondisi normal. Implementasi RUUBA ini diharapkan mampu menerobos situasi sosial yang abnormal, tidak teratur, kacau, dan berbahaya menjadi terkendali. Shirley Mattingly, (2002:113) idealnya kebijakan politik dan hukum penanggulangan bencana alam harus komprehensif, terpadu, berkesinambungan, berkeianjutan, efisien, fleksibel untuk menanggulangi berbagai kebutuhan yang sangat darurat dan penuh kepedulian (to address emergency needs' andcConcemed). ${ }^{37}$

Dalam mempersiapkan lahirnya RUUBA, terdapat tiga pendekatan. pertama, UUBA mengamanahkan bahwa bencana alam sebagai fenomena alamiah mustahil dapat dijauhi. Karena itu, kesadaran masyarakat perlu ditingkatkan agar mereka mampu mengadaptasikan dengan alam sekitar yang rentan bencana. Mereka juga perlu ditingkatkan keterampilan untuk dapat melakukan perlindungan (selp-help) atas bencana alam yang akan menimpa. ${ }^{38}$ kedua, lahirnya UUBA tidak saja memberikan kepastian akan adanya tanggungjawab dari pemerintah terhadap korban-korban bencana dan kerugian yang dideritanya, melainkan juga mendorong masyarakat untuk menyadari akan pentingnya pengetahuan bagi lahirnya relawan-relawan kemanusiaan yang profesional dan peduli pada kode etik bantuan kemanusiaan.

Ketiga, implementasi UUBA harus dapat dipergunakan secara khusus dan istimewa mengingat kondisi yang abnormal dihadapi korban sangat darurat dan membahayakan. Karena itu, tiga prinsip pertolongan darurat yaitu situasi kritis (the sense of crisis) dan situasi gawat darurat (the sense of urgency) dan situasi yang penuh tanggung jawab (the sense of responsibility) mestinya harus dapat menjiwai nilai peraturan hukum penanggulangan bencana alam.

\section{Simpulan}

Prinsip-prinsip dasar hukum internasional yang telah menjadi status pengungsi atau IDP's sebagai korban béncana, kerjasama bantuan kemanusiaan, dan peran dilakukan oleh PBB seharusnya diakomodir oleh RUUPBA sebagai payung hukum nasional. Upaya-upaya pencegahan, mitigasi dan pengumpulan informasi, dan data-data, penanggulangan dan evakuasi bersifat gawat, termasuk realisasi program rekonstruksi dan rehabilitasi merupakan hakhak dasar bagi korban yang merupakan tanggung jawab negara telah menjadi keniscayaan untuk di atur oleh UUPBA. Sebagai-

${ }^{37}$ Lihat Shirley. Mattingly, Policy Legal and Institutional Arrangements in Regional Workshop on Best Practies in Disaster Mitigation Lesson Learned from the Asian Urban Disaster Mitigation Program and other Initiatives, (Bali indonesia 24-26 September 2002), Hal 113

${ }^{38}$ Ibid., Hal 109-111 
mana halnya, pengaturan itu perlu ditetapkan bagi mekanisme keterlibatan masyarakat internasional dan nasional sebagai relawan dalam melakukan bantuan kemanu-siaan.

Keterlibatan relawan asing termasuk organisasi internasional dalam melakukan pertolongan dan rehabilitasi seperti UNHCR, IOM, WHO, FAO, baik terhadap pengungsi asing dan domestik sebagai kewajiban negara untuk memberikan pelayanan secara adil mutlak diperlukan. Namun, tanpa kehadiran Komisi Nasional Penanggulangan Bencana Alam yang responsif, independen, dan profesional, kehadiran UUPBA tidak akan banyak artinya. Kehadiran UUPBA diharapkan dapat mengubah paradigma lama yaitu perilaku negara memberikan pertolongan bersifat sukarela dan belas kasihan, menjadi kewajiban yang harus dipertanggungjawabkan. Konsekuensinya, jika negara atau pemerintah tidak mampu melakukan tugas dan pertolongan gawat darurat yang memadai, legal action yang dilakukan korban dapat perlindungan hukum secara pasti.

\section{Daftar Pustaka}

Alston International Human Right in Conteks: Law, Politics and Moral. Henny J. Steiner $\&$ Philip Alston. Oxpord Clarendon Press. 1996.

Christine Gray The Use of Force and The International Legal Order. Malcolm. D. Evan 2003.

Draft Awal Rencana Rehabilitasi dan Rekonstruksi Masyarakat Aceh dan Sumatera Utara R3MAS, 28 Februari 2005.

General Assembly, Resolution Adopted by The

General Assembly 581/214. International
Strategy for Disaster Reduction $78^{\text {th }}$ plenary meeting. 23 December 2003: General Assembly. Natural Disaster and Vulnerability 58/215 27 February 2004.

Ian Brownlie (ed) Basic Documents on Human Rights. Oxfrod: Clarendon Express. 1971.

Thontowi. Jawahir, Hukum dan Bencana Alam, JICA - FH UII Yogyakarta, 2002

—... Legal System Related to Natural Disaster in Indonesia. Jica-IMPRESS, Yogyakarta 2003

Roberta Cohen and Francis M. Deng Masses in Flight : The Global Crisis Displacement of Intemally. 1998.

Sarwidi,"Sebab Akibat Bencana Alam Terhadap Masyarakat Indonesia". Makalah disampaikan dalam Diskusi Terbatas IMPRESS. tanggal 26 Februari 2005.

Shirley Mattingly, Policy Legal and Institutional Arrangements in Regional Workshop on Best Practies in Disaster Mitigation Lesson Learned from the Asian Urban Disaster Mitigation Program and other Initiatives. Bali Indonesia 24-26 September 2002.

United Nation:World Conference on Disaster Reduction. Kobe, Kyoto, Japan.

Walter Kalin, Guiding Principles on Internal Displacement: Annotations; Studies in Transnational Legal Policy. № 32. The American Society of International Law, The Brooking Intitution, Project on Internal Displacement. 2000.

Kedaulatan Rakyat 7 April 2005

Kompas 29 Desember 2005.

Kedaulatan Rakyat 6 Januari 2005.

Kompas 31 Maret 2005. 